\title{
The Response of Freshwater Ecosystems to Climate Variability Associated with the North Atlantic Oscillation
}

\author{
Dietmar Straile ${ }^{1}$, David M. Livingstone ${ }^{2}$, Gesa A. Weyhenmeyer ${ }^{3}$, D. Glen George ${ }^{4}$
}

The North Atlantic Oscillation (NAO) affects the physics, hydrology, chemistry and biology of freshwater ecosystems over a large part of the Northern Hemisphere. Physical impacts of the NAO include effects on lake temperature profiles, lake ice phenology, river runoff and lake water levels. These physical and hydrological responses influence the chemistry and biology of fresh waters by affecting the leaching of nutrients from the soil and by altering the distribution of nutrients and oxygen in lakes. Finally, the population dynamics of freshwater organisms on several trophic levels-including autotrophs, herbivores and vertebrate predators-are directly and indirectly linked to the NAO via food-web interactions. As a result, the effects of mild winters associated with the positive index phase of the NAO can influence the food-web characteristics of lakes in summer. A considerable body of evidence documents the importance of these indirect and food-web mediated effects of the NAO, which might even result in ecosystem regime shifts. Owing to the large-scale impact of the NAO, lakes exhibit spatial coherence over large areas with respect to both physical and biological properties. This coherence is modified by geographical factors such as altitude and latitude, and by lake-specific characteristics such as depth and trophic status.

\section{INTRODUCTION}

Freshwater ecosystems have been repeatedly shown to respond significantly to large-scale climatic fluctuations [e.g., Strub et al., 1985; Firth and Fisher, 1992; George and Taylor, 1995; Anderson et al., 1996; Schindler, 1997]. Because human demand for high-quality fresh water is continually increasing, the practical relevance of such respons-

\footnotetext{
${ }^{1}$ Limnological Institute, University of Konstanz, Konstanz, Germany

${ }^{2}$ Water Resources Department, Swiss Federal Institute of Environmental Science and Technology (EAWAG), Dübendorf, Switzerland

${ }^{3}$ Department of Environmental Assessment, Swedish University of Agricultural Sciences, Uppsala, Sweden

${ }^{4}$ Centre for Ecology and Hydrology, Windermere, U.K.
}

es for the large-scale management of inland waters is now gradually beginning to be realized. Specifically, the impact of the North Atlantic Oscillation on lacustrine systems, especially in Europe, is becoming a topic of some importance. Briefly summarizing the information given more extensively in other parts of this volume, the North Atlantic Oscillation (NAO) represents a large-scale fluctuation in the air pressure difference between the Azores High and the Iceland Low [e.g., Hurrell et al., this volume]. It dominates much of the atmospheric behavior in the North Atlantic region, and is known to influence air temperature and precipitation over large areas of the Northern Hemisphere in winter [e.g., Hurrell, 1995; Hurrell and van Loon, 1997]. It is commonly represented in terms of an index based on the difference of the sea-level air pressure measured at a meteorological station close to the center of the Azores High and that measured at a station in Iceland [e.g., Jones et al., this volume]. Positive winter values of an NAO index correspond to a strong meridional pressure gradient that results in strong westerly winds transporting warm, moist maritime air across Europe, giving rise to warm, wet winters there. In contrast, low NAO index values correspond to weak westerlies and cold, dry winters in Europe. 
Here we will discuss the response of freshwater ecosystems to NAO-mediated changes in temperature regimes and water balances. Impacts of the NAO on lakes and rivers have been documented within a region stretching from Lake Mendota in central North America to Lake Baikal in eastern Siberia, and from Lake Kallavesi in Finland to the Caspian Sea (Figure 1). They can affect the physical, chemical and biological characteristics of these systems. The biological characteristics affected include plankton populations, community structure, and the food web.

Our review will not be one of individual case studies. Instead, we adopt an ecosystem approach to the impacts of the NAO, starting with its immediate effects on the physical characteristics of lakes, and continuing with the consequences of these physical responses for lake chemistry and biology. Finally, we consider more indirect biologically mediated chemical and food-web responses to the NAO.

\section{PHYSICAL RESPONSES}

\subsection{Lake Temperatures}

The heat balance of a lake is governed predominantly by five heat exchange processes involving four meteorological driving variables; viz. air temperature, cloud cover, water vapor pressure and wind speed [Edinger et al., 1968]. Of these driving variables, air temperature is generally regarded to have the most significant influence on lake temperature variability [e.g., Henderson-Sellers, 1988; Hondzo and Stefan, 1992; 1993]. Air temperature is involved explicitly in three of the five heat exchange processes (convective sensible heat exchange, evaporative heat exchange and the atmospheric emission of long-wave radiation incident on the lake), and the surface temperature of a lake tends asymptotically towards an equilibrium temperature that is often close to the ambient air temperature despite deviations induced by radiative heat exchange and wind mixing [Dingman, 1972; Arai, 1981]. Thus, despite the fact that air temperature is only partially responsible for the heat balance of a lake, empirical studies show that lake surface temperatures are closely related to local and regional air temperatures on both short and long time scales [McCombie, 1959; Shuter et al., 1983; Livingstone and Lotter, 1998; Livingstone et al., 1999; Livingstone and Dokulil, 2001].

Air temperatures over large areas of the Northern Hemisphere are known to be influenced significantly by the NAO [e.g., Hurrell, 1995]. Thus, even neglecting a possible NAO influence on cloud cover, water vapor pressure and wind speed, the NAO influence on air temperature alone might well suffice to generate an NAO signature in lake surface temperature via the relevant air-water heat exchange processes.

The response of a lake to meteorological forcing is most immediate at the lake surface. Because of the relative ease of obtaining surface data, historical time-series of surface temperature tend to go back further in time than time-series of temperatures at depth, facilitating long-term comparison with meteorological data and with indices of the NAO. Based on 40 years of data, George et al. [2000] showed a highly significant correlation between the winter NAO and the winter surface temperatures of Esthwaite Water and Windermere in the English Lake District, with as much as 40-50\% shared variance. Likewise, winter (DJF) temperature in Black Brows Beck, a small stream in the English Lake District, was highly correlated with the winter NAO, with over $60 \%$ shared variance [Elliott et al., 2000]. Because of its proximity to the North Atlantic, a strong

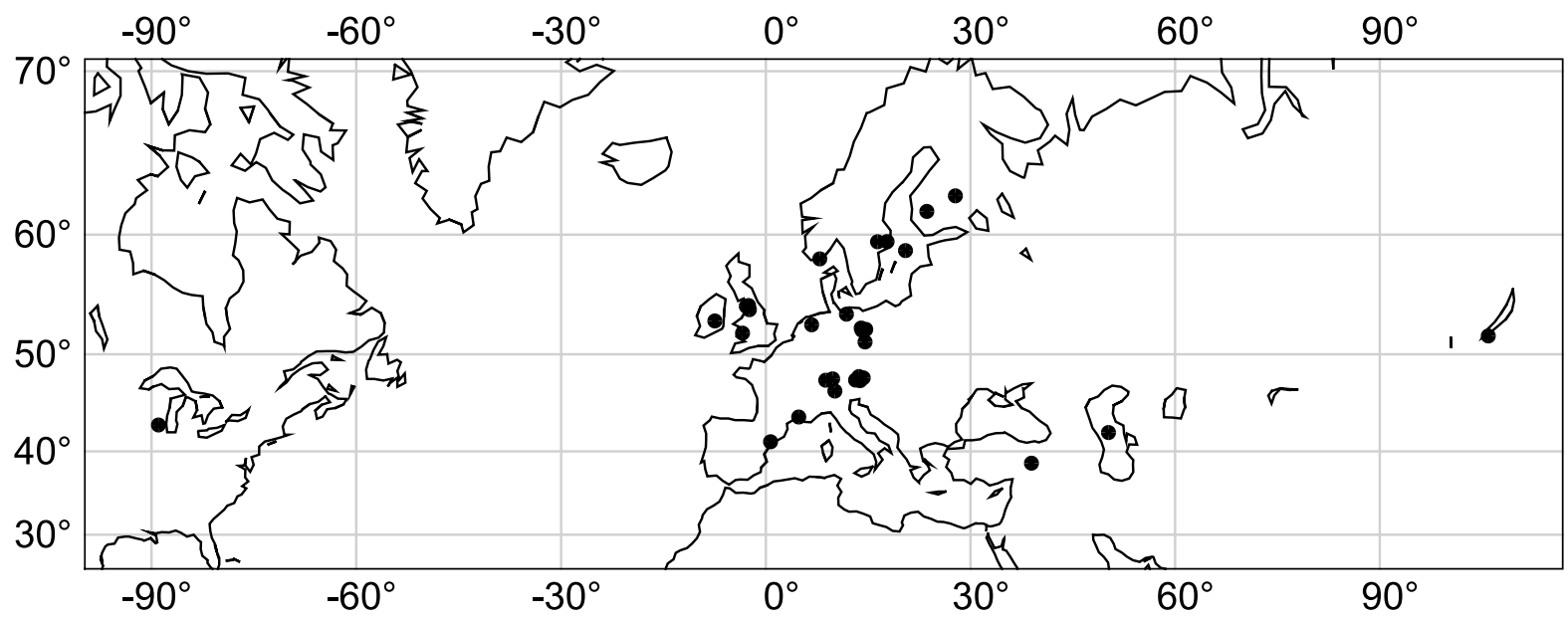

$70^{\circ}$

$60^{\circ}$

$50^{\circ}$

$40^{\circ}$

Figure 1. Map showing the locations where impacts of the NAO on physical, chemical and/or biological characteristics of freshwater ecosystems have been demonstrated. 
NAO influence might be expected in the western maritime region of Europe. However, studies in the European perialpine region, in which a strong NAO influence might not be expected $a$ priori, have also revealed a significant NAO influence on surface or near-surface lake water temperatures. Based on $16 \mathrm{yr}$ of data, Straile [2000] detected a significant NAO influence on the water temperature at $8 \mathrm{~m}$ depth in Lake Constance, with over 30\% shared variance with the water temperature in March. Average winter (JFM) and spring (AMJ) temperatures in Lake Veluwe, in the Netherlands, from 1959 - 1999 were found to be highly correlated with the NAO index $(\mathrm{r}=0.75, \mathrm{p}<0.01$ and $\mathrm{r}=0.49$, $\mathrm{p}<0.01$ respectively [Scheffer et al., 2001a]). In an analysis of 80 years of monthly mean surface temperatures from eight lakes in Austria, Livingstone and Dokulil [2001] found surface temperatures to be highly spatially coherent among lakes in all seasons, and to reflect much of the temporal structure inherent in the regional air temperature. Comparison of an average Austrian lake surface temperature with Hurrell's [1995] winter NAO index revealed a significant correlation from January to May, with over 25\% shared variance in March. In each of the months January to May, the NAO signal in the average Austrian lake surface temperature was found to be even stronger than the NAO signal in regional air temperature, suggesting that although air temperature is probably the most important meteorological driving variable transmitting an NAO signal to the lakes, it is unlikely to be the only one. An additional result concerns the blocking of the NAO influence by ice cover: in general, the NAO signal detected in lake surface temperature was found to be strongest in lowland lakes with infrequent or short periods of ice cover, becoming successively weaker with altitude, as the frequency and duration of ice cover events increased.

Fluctuations in the surface temperature of a lake are transmitted downwards by vertical mixing processes. However, although the response of lake surface temperature to meteorological forcing is fairly immediate, this is not true of the temperature of the deeper water. A lake tends to filter out high-frequency temperature fluctuations with increasing depth, implying that, although short-period fluctuations in air temperature may be reflected only in water temperatures in the uppermost few meters of a lake, longer-period fluctuations may well be reflected in some way in the water temperature in the depths of the lake [Livingstone, 1993]. These fluctuations, however, are only transmitted to the deep water of the lake when thermal stratification is weak, i.e., during the winter half-year. In late winter and early spring, when the NAO influence on lake surface temperature is at its greatest, holomictic lakes (lakes that can undergo mixing down to the lowest depths without hindrance from chemical stabilization of the water column) usually become homothermic, with vigorous vertical mixing occurring during the so-called spring turnover. Thus at this time of year, not only surface temperatures, but also deep-water temperatures, are directly determined to a large extent by the prevailing meteorological conditions. Any NAO signal present in the meteorological variables that determine the lake heat balance at this time of year will therefore be transmitted not only to the upper layers of the lake, but to the whole water body. Because the thermal stratification that subsequently ensues effectively isolates the hypolimnion (the region below the thermocline) from the epilimnion (the region above the thermocline), and thus from any further climatic forcing mediated by the epilimnion, deep-water temperatures during the summer half-year are determined by, and highly correlated with, the deep-water temperature attained at the end of spring turnover [Robertson and Ragotzkie, 1990; Hondzo and Stefan, 1993; Livingstone, 1993]. Thus, any climatic signal captured in the hypolimnetic temperature of a lake during spring turnover is likely to persist for some months afterwards.

With respect to the NAO, this was analyzed by Gerten and Adrian [2001] in three different lakes in northern Germany. They were able to show that a signal from the winter NAO was present in the temperatures of all three lakes at all depths, but that the persistence of this signal differed significantly from lake to lake. In the epilimnion of all three lakes, the NAO signal was confined to late winter and early spring, implying that the advent of thermal stratification in late spring effectively eliminates any influence of the previous winter's NAO above the thermocline in summer (the effect of the summer NAO is negligible). In the hypolimnion, however, the response varied from lake to lake. In shallow, polymictic Müggelsee, the NAO signal was confined to spring. In shallow, dimictic Heiligensee it persisted, albeit with a weakening tendency, throughout much of the summer. Finally, in much deeper, dimictic Stechlinsee, the NAO signal persisted throughout the whole of summer and autumn, only being eliminated by vertical mixing in December. Thus, although an NAO signal is likely to be present to some extent in the temperature of all lakes within the NAO's area of influence, individual lake characteristics can cause major modifications of this signal.

Using a superposed epoch analysis, Figure 2 illustrates the effect the NAO can have on the longer-term development of the water temperature in an even deeper lake, Lake Zurich (136 m deep), located in Switzerland. In this analysis, the 50 years from 1948 to 1997 were first divided into two 25-yr groups according to whether their winter NAO index was less than or greater than the median value (0.42). For each group, the monthly mean lake water temperatures 


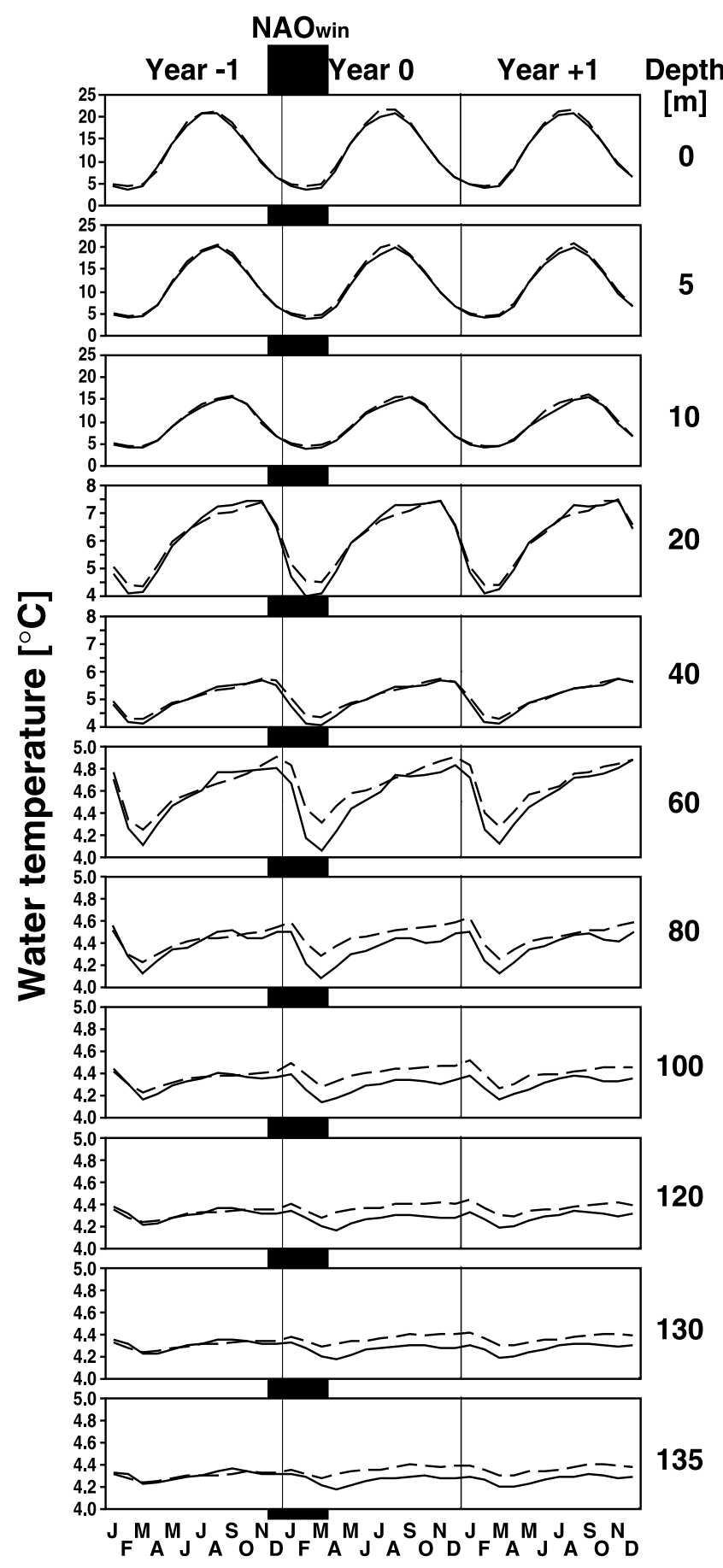

Figure 2. Superposed epoch analysis of water temperatures at 11 depths in Lake Zurich, Switzerland, with respect to the occurrence of high and low winter indices of the NAO. The period covered by the winter NAO index NAOwin (December-March) is shaded. The figure shows water temperatures averaged over all years in which NAOwin was greater (dashed lines) or less (solid lines) than the median value. See text for detailed explanation. at a particular depth were then averaged over all $25 \mathrm{yr}$ for the 3-yr "epoch" encompassing the year of the NAO index taken ("Year 0") and the years immediately before ("Year - 1") and after ("Year 1"). This analysis shows up the effect of high and low NAO indices on the development of the temperature regime of the lake. Lake Zurich does not lie particularly close to the center of action of the NAO. Nevertheless, a significant difference is apparent in the way the thermal structure of the lake develops following winters with a high or low winter NAO index. High (low) winter NAO indices tend to result in high (low) temperatures in the hypolimnion in late winter and early spring, which persist not only throughout the following summer stratification period (Year 0), but carry over through the subsequent winter into the next summer stratification period (Year 1). In the year previous to the occurrence of either a high or low NAO index (Year -1), no significant difference in lake temperature is observed at any depth, indicating that the causative event does indeed occur at the beginning of Year 0 . The persistence of the NAO effect from one year to the next is possible because Lake Zurich, although holomictic, does not always circulate fully each year. During warm winters (high NAO index) stratification in Lake Zurich may persist uninterruptedly from one summer to the next [Livingstone, 1993; 1997a]. A similar pattern has been observed in Lake Constance, where it has also been shown that the thermal stability of the water column in winter and spring is positively related to the winter NAO index [Straile et al., in prep.].

In general, epilimnetic temperatures of all lakes within the region of influence of the NAO are likely to show a large degree of spatial coherence in winter and spring that is induced by spatial coherence in meteorological forcing related to the winter NAO. In the hypolimnion, however, the persistence of the winter NAO signal can vary substantially from lake to lake, depending on individual lake characteristics such as lake morphometry and degree of susceptibility to meteorological forcing in summer.

\subsection{Lake Ice Cover}

Historical ice phenology records from lakes distributed throughout the Northern Hemisphere are known to reflect the general rise in global air temperature that has occurred over approximately the last 150 years [Magnuson et al., 2000]. Such records are therefore not only of local interest, but also are valuable indicators of large-scale climate forcing such as that associated with the NAO. As in the case of lake surface temperatures, the timing of freeze-up (ice-on) and break-up (ice-off) of a lake, although influenced by several meteorological variables, appears to be related most strongly to air temperature [Palecki and Barry, 1986; 
Ruosteenoja, 1986; Robertson et al., 1992; Vavrus et al., 1996; Livingstone, 1997b]. Because the NAO affects air temperatures over large parts of the Northern Hemisphere [Hurrell, 1995; Hurrell, 1996; Hurrell and van Loon, 1997], it also leaves a signal in the break-up dates of lakes distributed widely over the Northern Hemisphere [Weyhenmeyer et al., 1999; George, 2000a; Livingstone, 2000]. However, these signals are not always constant in time [Livingstone, 2000].

The strongest NAO influence on Eurasian winter air temperatures appears to occur north of about $60^{\circ} \mathrm{N}$ [Hurrell, 1996; Hurrell and van Loon, 1997]. Finland, which lies almost entirely north of $60^{\circ} \mathrm{N}$, contains many lakes with long historical time-series of ice phenology observations [Palecki and Barry, 1986]. An analysis of break-up data from two of these lakes (Kallavesi and Näsijärvi) from the 1830 s to the present reveals a fluctuating, but always strong, NAO signal in the entire record [Livingstone, 2000, Figure $3 a]$. The signal strength appears to vary with a periodicity of about $30 \mathrm{yr}$, with the proportion of shared variance generally ranging between $10 \%$ and $30 \%$, but achieving a maximum of $43 \%$ - surprisingly high in view of the complexity involved in the thawing of lake ice and the simplicity of the parameterization of the climatic effects of the NAO by the winter NAO index. Apart from the fluctuations in signal strength, no longer-term trends or abrupt alterations in the signal strength are apparent (Figure 3a).

Air temperatures in Siberia also exhibit a substantial NAO influence [Hurrell, 1996; Hurrell and van Loon, 1997]. The largest lake on earth with respect to volume, Lake Baikal, is located in Siberia and might therefore also be expected to be subject to the influence of the NAO. The analysis of a 128-yr ice record did indeed reveal the timing of break-up of Lake Baikal to be related not only to air temperatures over an extensive area of northern Asia encompassing most of Siberia and parts of northern China, but also to the winter NAO [Livingstone, 1999]. However, there are distinct differences between Lake Baikal and the Finnish lakes with respect to the NAO signal in the ice phenology data. In the Lake Baikal data, a significant NAO signature can be detected only in the latter part of the series, beginning in the 1918-1967 50-yr data window and becoming generally stronger as time progresses [Livingstone, 1999; 2000]. An NAO signature detected in the timing of break-up of Lej da San Murezzan (Lake St. Moritz), a high-altitude lake in Switzerland, was found to behave similarly to that detected in the Lake Baikal data, with a significant signature detected only in the latter part of the series [Livingstone, 2000; Figure 3b]. The most interesting behavior, however, is that exhibited by Lake Mendota, Wisconsin. In this lake, break-up during the second half of the 20th century has been influenced more by the El-Niño/Southern Oscillation (ENSO) phenomenon than by the NAO [Robertson, 1989; Anderson et al., 1996; Livingstone, 2000]. This is to be expected in view of the fact that air temperatures in central North America from 1935 to 1994 appear to have been influenced much more by the Southern Oscillation (SO) than by the NAO [Hurrell, 1996]. However, the ice phenol-

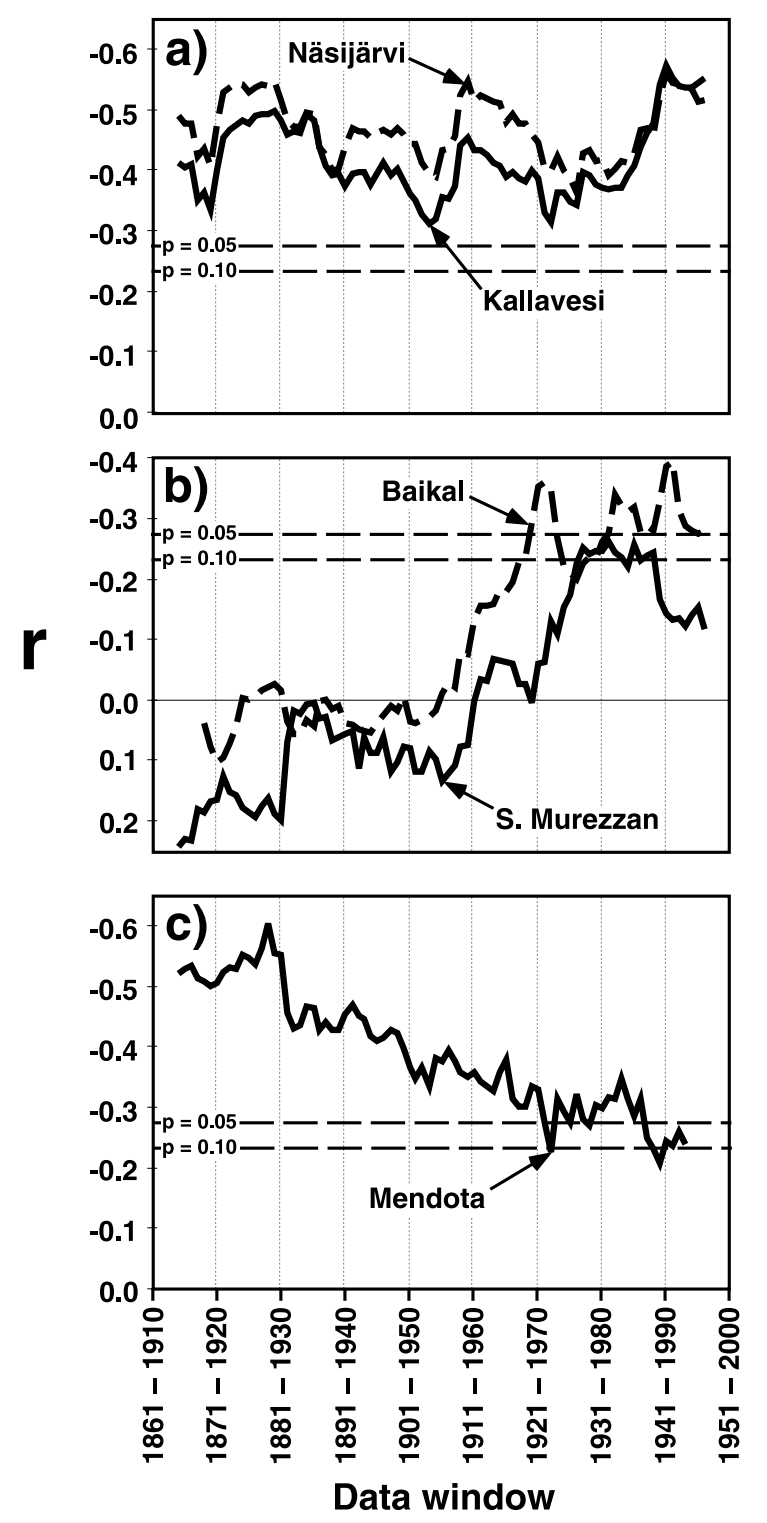

Figure 3. Running correlation coefficients (r) between the Julian day of break-up and the 3-monthly (DJF) winter index of the preceding NAO, based on 50-year data windows, for (a) Kallavesi and Näsijärvi (Finland); (b) Baikal (Russia) and San Murezzan (Switzerland); and (c) Mendota (USA). The $\mathrm{p}=0.05$ and $\mathrm{p}=0.10$ significance levels $(\mathrm{n}=50,2$-tailed t-test) are as shown (based on Livingstone [2000]). 
ogy data from Lake Mendota suggest that this situation may have been different in the recent past. During the last part of the 19th century and the first part of the 20th century, there is no evidence that breakup on Lake Mendota was influenced by El Niño [Robertson, 1989] or the SO [Livingstone, 2000], but there is evidence of a strong correlation with the winter NAO [Livingstone, 2000; Figure 3c]. This correlation has become steadily weaker during the course of the 20th century (Figure 3c). Taken in conjunction with the simultaneous increase in the influence of the NAO on the breakup of the Swiss and Russian lakes (Figure 3b), this may point to a shift in Northern Hemisphere quasi-stationary planetary wave patterns having occurred during the first half of the 20th century [see also Jones et al., this volume]. This may be connected to a change in the sign of the correlation between the air pressure in the Iceland Low and in the Aleutian Low that occurred in the late 1930s [van Loon and Madden, 1983].

\subsection{Lake Level Changes and River Discharge}

Like air temperature, precipitation over large areas of the Northern Hemisphere is known to be influenced significantly by the NAO [Hurrell, 1995]. For instance, during a positive index phase of the NAO, winter precipitation increases in Northern Europe while it decreases in the Mediterranean area and the Middle East [Hurrell, 1995; Cullen and deMenocal, 2000]. Because the hydrology of inland waters is intimately linked to precipitation, an NAO influence on river discharge and on lake water levels would be expected, which has been confirmed by several studies on rivers and lakes distributed over various parts of Eurasia.

The runoff of rivers in western and northern Europe has increased with increasing NAO index. Kiely [1999], for example, showed that the increase in the runoff of Irish rivers that has occurred since the mid-1970s corresponds to the recent positive index phase of the NAO. The annual discharge of the Hafren and Gwy rivers in central Wales shared $41 \%$ and $31 \%$, respectively, of their interannual variance with the winter NAO index [Bradley and Ormerod, 2001]. The total river discharge into the Baltic Sea has increased with increasing NAO index, causing a reduction in salinity [Hänninen et al., 2000].

In the Mediterranean region and the Middle East, river runoff and lake water levels have decreased with increasing NAO index. Lloret et al. [2001] showed that interannual fluctuations in the runoff of the Rhône (France) and the Ebro (Spain) were synchronous and negatively correlated with an NAO index $(r=-0.4$ and $r=-0.26$, respectively, both $\mathrm{p}<$ 0.05), as was the Euphrates streamflow between 1938 and $1972(\mathrm{r}=-0.42, \mathrm{p}<0.02)$ [Cullen and deMenocal, 2000].
In an analysis of the climatic factors responsible for fluctuations in the level of the Caspian Sea, Rodionov [1994] showed that the NAO plays a dominant role, with a decline in the surface level of the Caspian Sea being linked to a positive NAO index and vice versa. The Caspian Sea surface level is determined mainly by the rate of water supply to the sea from the Volga basin to the north (modified, of course, by anthropogenic factors). About a year before a decline in the Caspian Sea surface level, a noticeable decrease in air pressure at higher latitudes over the North Atlantic tends to occur, coupled with an increase at lower latitudes (i.e., the positive index phase of the NAO). As a result, mid-latitude westerlies over the North Atlantic intensify, and storm tracks shift northwards. The transport of heat and moisture from the North Atlantic to the extreme north of European Russia increases, resulting in decreased ice cover on the Barents Sea. Simultaneously, the establishment of a highpressure cell over the Volga basin results in lower precipitation rates, lower runoff, and consequently a decline in the Caspian Sea surface level.

A rise in the Caspian Sea surface level tends to be preceded by the reverse climatic situation, in which air pressure increases at high latitudes and decreases at low latitudes (i.e., the negative index phase of the NAO), leading to weakened westerlies and more meridional atmospheric circulation. The establishment of a blocking ridge over the North Atlantic and an upper atmospheric trough over eastern Europe forces moisture-laden southerly cyclones to travel northeastward along the edge of the trough, resulting in heavy precipitation in the Volga basin and a consequent rise in the Caspian Sea surface level.

\section{CHEMICAL RESPONSES}

Physical responses to the NAO might result in secondary chemical responses, due for instance to changes in river inflow or in mixing or upwelling processes. Several studies point to the importance of changes in the leaching of nutrients into lakes and rivers in response to changes in the NAO. Alterations in winter temperature and precipitation result in changes in nutrient release from soil in the catchment area. For instance, Weyhenmeyer [in prep.] shows that total phosphorus, phosphate phosphorus, total nitrogen and nitrate nitrogen in March in the Galten Basin, a shallow basin of Lake Mälaren in Sweden, are all positively related to the nutrient transport from inflowing waters, winter air temperature and the winter NAO index. She suggests that in the colder winters that occur in low NAO index years, nutrient release from the frozen ground in the catchment area is reduced. Additionally, alkalinity and conductivity in surface waters throughout the year show a strong dependence on 
winter meteorological conditions [Weyhenmeyer, in prep.]. The effect of warmer winters on these two variables is persistent since catchment processes predominantly determine both during winter rather than internal lake processes, so seasonal variability is slight.

In contrast to the Swedish results, Monteith et al. [2000] observed that March nitrate nitrogen concentrations in nine lakes and six streams in the UK are strongly negatively correlated with the winter NAO index. In this case, low winter temperatures and freezing conditions causing frost damage to plants and roots were suggested to result in an increase in nitrate leaching. The seeming contradiction between the two studies might be related to the difference in winter severity and average March temperatures between Sweden and the UK. In the catchment area of the Galten Basin, March is still winter and the ground is normally frozen. In cold winters, nitrogen leaching in March is therefore negligible. In warm winters, however, nitrogen leaching begins in March, resulting in a positive relationship between the NAO and March nitrate nitrogen concentrations. In contrast, nitrogen leaching at the UK sites is at its maximum in winter and early spring, when biological demand and uptake in the catchment area are lowest. In this region, which experiences milder winters on average, rare freezing events increase nitrate leaching due to their damaging effects on plants, roots and microorganisms.

The input of nutrients into lakes might also vary with NAO-related changes in precipitation. For example, in small Blelham Tarn in the English Lake District, the winter concentration of dissolved reactive phosphorus is positively related to winter precipitation $(\mathrm{r}=0.61, \mathrm{p}<0.01)$. As precipitation in the UK is linked to the NAO, winter concentrations of dissolved reactive phosphorus in this lake are also positively correlated with the winter NAO index $(\mathrm{r}=$ $0.53, \mathrm{p}<0.01)$ [George, 2002]. Similar effects have been recorded in nearby Esthwaite Water [George et al., in prep.]. Increased precipitation in high NAO index years appears also to result in an increase in the wet deposition of chloride and other marine-derived ions at several sites in the UK [Evans et al., 2001]. At lake sites in north Wales, the Lake District and the Galloway district of southwest Scotland, concentrations of chloride and other marine-derived ions follow an approximately decadal cycle that is suggested to be in phase with the winter NAO. Marine-derived cations cause the displacement of absorbed acid cations such as hydrogen and labile aluminum in the soil, which can lead to acidification of runoff [Evans et al., 2001]. Acidification and recovery from acidification in these systems might therefore also be influenced by the NAO.

The patterns reported above stem mostly from observations on small, shallow lakes. Such systems often have short water residence times, and are therefore more likely to react rapidly to changes in inflow than are large water bodies. For instance, in the Lake District, a relationship between nutrients and the NAO was observed in comparatively small lakes such as Blelham Tarn and Esthwaite Water (see above), but not in the two large basins of Lake Windermere [George et al., in prep.]. In Lake Mälaren, the water chemistry is strongly linked to recent meteorology and the NAO only in the small, shallow Galten Basin, but not in other larger and deeper parts of the lake [Weyhenmeyer, in prep.]. Hence, the sensitivity of, for instance, nutrient concentrations to NAO variability seems to depend on the size of the lake.

The NAO has been shown to affect mixing processes in lakes (see above) and the ocean [e.g., Williams and McLaren, 2000; Oschlies, 2001]. This is important because mixing affects the distribution of nutrients and other particulate and dissolved substances in the water column. For example, spring turnover in lakes is an important process for the transport of oxygen into deeper water layers, and inhibition of spring turnover can result in deep-water anoxia. In high NAO index years, warm winters can indeed inhibit spring turnover, resulting in extreme deep-water oxygen depletion in some deep perialpine lakes [Livingstone, 1997a]. In Lake Constance, near-bottom oxygen concentrations during spring turnover and during the following summer have been shown to be negatively related to the winter NAO index [Straile et al., in prep.]. Climatic variations associated with the NAO can therefore have a major impact on the occurrence of oxygen deficiencies in lakes. The remediation of oxygen deficiency in the deep water of lakes is therefore only partially under the control of lake managers, and might be a problem in many deep lakes in the future despite reduced nutrient loadings [Livingstone and Imboden, 1996].

A reduction in the vigor of spring turnover additionally implies that nutrients (e.g., silicate and phosphorus) that have accumulated in the hypolimnion during the previous stratification period will not be homogeneously distributed vertically over the whole water column. Because of such climate-dependent differences in nutrient upwelling from year to year, nutrient concentrations in the epilimnion of Lake Constance tend to be lower in high NAO years than in low NAO years, whereas in the hypolimnion the opposite is the case [Straile et al., in prep.].

\section{BIOLOGICAL RESPONSES}

\subsection{Phytoplankton}

Many experimental studies have shown the growth and species composition of algae to depend strongly on light 
availability, temperature, and nutrient availability [e.g., Sommer, 1989; Reynolds, 1989; Huisman et al., 1999]. Because the NAO can exert a strong influence on these factors (see above), it is also likely to affect the phytoplankton.

The presence of ice cover on lakes will reduce the light available for phytoplankton photosynthesis, resulting in the earlier (later) occurrence of peaks in algal growth with earlier (later) ice-off. The timing of the phytoplankton peak in Lake Erken (Sweden) and in Müggelsee (Germany) was found to be related to the timing of ice-off [Weyhenmeyer et al., 1999] and to the duration of ice-cover [Adrian et al., 1999], respectively. As the timing of ice-off is linked to the NAO in both lakes [Weyhenmeyer et al., 1999; R. Adrian, personal communication], so is the timing of the spring bloom, as well as the late winter and early spring phytoplankton biomass in Müggelsee [Weyhenmeyer et al., 1999; Gerten and Adrian, 2000; Straile and Adrian, 2000]. Additionally, reduced ice cover in Plußsee (Germany) following mild winters has been suggested to be responsible for lower transparency in early spring, indicating a higher phytoplankton biomass [Güss et al., 2000].

In addition to overall phytoplankton biomass, phytoplankton species composition can also be affected by ice dynamics, and hence by the NAO. High NAO index years have been found to favor the growth of diatoms relative to other phytoplankton species in both Lake Erken and Müggelsee. This is because extensive diatom blooms develop only under ice-free conditions, as diatom species need turbulent conditions to prevent them sinking out of the euphotic zone. In contrast, the dinoflagellate Peridinium is able to grow well under the ice of Lake Erken when snow cover is low and the ice is clear [Weyhenmeyer et al., 1999]. In Müggelsee, earlier ice-off results in an earlier diatom peak, whereas the timing of the biomass peaks of other phytoplankton taxa is not affected by ice duration [Adrian et al., 1999]. Hence in both Lake Erken and Müggelsee, the importance of diatoms relative to other phytoplankton is greatest in high NAO index (early ice-off) years. Obviously, changes in ice phenology due to the NAO cannot have impacts on phytoplankton in lakes that do not normally freeze during winter. In Lake Constance, for example, no influence of the NAO on the phytoplankton dynamics in early spring could be detected. Using a one-dimensional numerical hydrodynamical model, Gaedke et al. [1998] showed that phytoplankton growth in this deep lake was only possible when no deep mixing (below $20 \mathrm{~m}$ depth) of algal cells occurred, either because of the onset of stratification or the absence of wind.

Studies so far have documented the importance of the NAO to phytoplankton growth and species composition only via its effect on ice-cover dynamics. Regarding the potential importance of water temperature, it should be noted that phytoplankton population growth has been observed at quite low water temperatures, e.g. under the ice in Lake Erken [Weyhenmeyer et al., 1999] or during late winter in the absence of mixing in Lake Constance [Gaedke et al., 1998]. This suggests that the NAO may be influencing lake phytoplankton in spring primarily through its effect on light availability (via ice cover), rather than its effect on water temperature. Although it is clear that water temperature plays an important role in controlling phytoplankton growth rates [Raven and Geider, 1988], an influence of the NAO on lake phytoplankton populations via such a temperature control mechanism would seem to be of only secondary importance. However, it has been suggested that an increase in water temperatures was responsible for the earlier occurrence of cyanobacteria in the 1990s in Sweden's largest lakes (Mälaren, Vänern and Vättern) in late spring and early summer [Weyhenmeyer, 2001]. Up to now, no studies, either in limnetic or marine environments, have documented the consequences of NAO-related changes in nutrient availability on phytoplankton dynamics. For foodweb mediated effects of the NAO on phytoplankton populations, see section 5.2 below.

\subsection{Zooplankton}

The spring succession in temperate lakes is characterized by high growth rates of several zooplankton species in response to increased water temperature and algal food supply [Sommer et al., 1986]. For instance, the biomass of Daphnia in Lake Constance increased on average almost 1000-fold from less than $10 \mathrm{mg} \mathrm{C} \mathrm{m}^{-2}$ to $1000 \mathrm{mg} \mathrm{C} \mathrm{m}^{-2}$ within approximately 6 weeks [Straile, 2000]. Interannual variability in the Daphnia growth rate during this periodand, as a result, in the Daphnia biomass in May-is strongly related to water temperature, and consequently to the NAO. This correlation is most probably due to a physiological response of Daphnia egg development and growth rates to increased water temperatures, and is not mediated by an increase in the food supply. During late winter, the growth of Daphnia is restricted by a low food supply and low temperatures. However, after the onset of stratification this "colimitation" switches to a temperature control of Daphnia growth, because water temperature increases more slowly than phytoplankton biomass [Gaedke et al., 1998; Straile, 2000]. Hence, during the period of exponential Daphnia population increase, it is water temperature, and not food supply, that controls Daphnia growth. Subsequent studies in different lakes have shown that in addition to daphnids, the abundances of other cladoceran species, and also of rotifer species, are related to the NAO. In Müggelsee, spring abun- 
dances of Daphnia sp., Bosmina sp. and of the rotifer Keratella have been found to be higher in high NAO index years than in low index years [Gerten and Adrian, 2000; Straile and Adrian, 2000]. Furthermore, the timing of the peak abundance of several rotifer species (Keratella cochlearis, Keratella quadrata, Brachionus angularis, Brachionus calyciflorus, Polyarthra dolichoptera) in this lake is significantly related to the duration of ice cover [Adrian et al., 1999], which suggests a link to the NAO.

In Bautzen Reservoir, Germany, high water temperatures during late winter/early spring are associated with high average Daphnia biomass in April/May [Benndorf et al., 2001]. The Daphnia biomass was not directly linked to the NAO by Benndorf et al. [2001]; however, the geographical location of this reservoir $\left(51^{\circ} 10^{\prime} \mathrm{N}, 14^{\circ} 26^{\prime} \mathrm{E}\right)$ suggests a possible relationship with the NAO. To examine this, we digitized their Fig 3b, estimated the mean Daphnia biomass for the years 1983-1996, and correlated it with the winter NAO index. We found the mean Daphnia biomass in Bautzen Reservoir during April/May to be related significantly to the NAO $(\mathrm{r}=$ $0.52, \mathrm{p}<0.05)$. The impact of the NAO on Daphnia spring dynamics in two lakes and one reservoir that are more than $700 \mathrm{~km}$ apart, and that differ strongly in many respects limnologically, suggests that many lakes within central Europe might be similarly affected by the NAO.

Increased water temperatures might also have negative impacts on zooplankton species, since enhanced metabolic requirements in warmer water might not be met by corresponding increases in phytoplankton production. This mechanism has been suggested for the negative relationship between the NAO and Daphnia abundance in winter in Esthwaite water [George, 2000b]. Additionally, competition between Daphnia and a calanoid copepod, Eudiaptomus gracilis, whose abundance was positively related to the NAO during this period, might have contributed to the decline of Daphnia in mild winters [George and Hewitt, 1999].

Up to now the only freshwater copepod species whose abundance is known to be related to the NAO is the calanoid copepod Eudiaptomus in Esthwaite water [George and Hewitt, 1999]. In addition, Adrian [1997] showed that the abundance of copepod species in Heiligensee (Berlin, Germany) is associated with winter temperatures. Although copepod abundances were not linked directly to the NAO in this work, the proximity of Heiligensee to Müggelsee suggests that an NAO influence is likely. All other reported links between zooplankton and the NAO concern cladoceran and rotifer species. This suggests that the life history of zooplankton species may be an important factor governing their response to increased water temperatures and to the NAO. In contrast to copepods, cladocerans and rotifers reproduce parthenogenetically, which enables their popula- tions to grow exponentially during spring, thus allowing them to double their population sizes within a short period. Hence, even a small change in temperature - and consequently in growth and development rates - during the period of exponential increase can result in a difference in population size large enough to be detected easily during long-term sampling programs. During a period in which cladocerans and rotifers reproduce rapidly, more slowly developing copepods might complete just one life cycle. An increase in temperature will certainly speed up the ontogenetic development of copepods also; however, it would take a long time for temperature differences to show up as differences in overall abundance. This suggests that changes in temperature are more likely to have a large impact on copepod populations when they result in changes in food availability and/or predation pressure that alter the copepods' survival chances. Supporting this hypothesis, changes in copepod abundance were indeed found to be associated not only with changes in water temperature but also with changes in food availability in both Esthwaite Water and Heiligensee [Adrian, 1997; George and Hewitt, 1999].

\subsection{Zoobenthos}

The response of freshwater benthos to the NAO has been less thoroughly investigated than that of the plankton. The only two studies reporting a relationship were conducted in the UK [George, 2000a; Bradley and Ormerod, 2001]. Interannual variability in the emergence of alder-flies, Sialis lutaria, from the littoral zone of Lake Windermere was studied by Elliott [1996] from the 1960s to the 1990s and shown to be related to the NAO by George [2000a]. Year-to-year variations of the date of the first emergence of adults shared $20 \%$ variance with the winter NAO index and $92 \%$ variance with average spring water temperatures, suggesting a rather direct control of the timing of emergence by water temperature.

During 1984-1998, Bradley and Ormerod [2001] studied macroinvertebrate communities in 8 streams in central Wales that differed in chemistry and catchment land use. The persistence of these communities between pairs of successive years was analyzed with Spearman's rank correlation coefficient and Jaccard's coefficient of similarity. Invertebrate communities in all different stream types switched significantly from being highly persistent during negative phases of the NAO to unstable during positive phases. The overall abundance of macroinvertebrates was not related to the NAO, at least partially because of opposing relationships of individual species with the NAO; e.g. the relationship of Nemurella picteti, Elmis aenea, Hydropsyche siltalai, and Paraleptophlebia submarginata to the phase of the NAO was found to be negative, while 
that of Chloroperla tripunctata was found to be positive. However, the actual mechanisms linking the abundance of individual species and community persistence in the Welsh streams to the NAO are unclear.

\subsection{Vertebrate Predators}

Evidence for an impact of the NAO on freshwater fish species is rare. This contrasts with marine systems, where the recruitment of various fish species has been shown to be linked to the NAO [e.g., Fromentin et al., 1998; Stenseth et al., 1999; Ottersen and Loeng, 2000; Drinkwater et al., this volume]. In most cases this relationship has been attributed to the direct effects of temperature, although the actual mechanisms that have been suggested to underlie the climate-recruitment links often remain speculative [Ottersen et al., 2001]. As the temperature of many lakes and rivers is closely related to the phase of the NAO, we might also expect a link between the NAO and freshwater fishes. This link has been suggested to exist for sea trout (Salmo trutta) in Black Brows Beck, a small stream in the English Lake District [Elliott and Hurley, 1998] The authors developed an individual-based model to predict sea trout fry emergence dates. The model predictions were validated by 8 years of field data. In a subsequent study, Elliott et al. [2000] correlated the predicted emergence dates with the NAO index and found $41 \%$ shared variance. Elliott et al. [2000] suggested that water temperature was the mediating factor, as water temperature in this stream was correlated with the phase of the NAO and is the main driving factor in the model of Elliott and Hurley [1998]. Water temperature has also been suggested to be the most important factor determining the recruitment of whitefish (Coregonus lavaretus) in Lake Constance [Eckmann et al., 1988] and perch (Perca fluviatilis) in Bautzen Reservoir [Mehner et al., 1998]. Nevertheless, the link between the NAO and recruitment was not investigated in these studies, and more work needs to be done on this topic in the future.

In addition to fish, birds may also be important predators in freshwater environments. For example, dippers (Cinclus cinclus) are important predators of macrobenthos in small streams. Change in the population size of dippers in southern Norway has been found to be positively related to winter temperature and to the winter NAO index [Sather et al., 2000]. Mild winters changed the local dynamics of this dipper population by increasing the carrying capacity of the habitat, but they also increased the immigration rate [see also Mysterud et al., this volume]. A second study, in which breeding phenology along the riparian habitat of streams flowing into Lake Zurich was investigated from 1992 to 2000 , supports the importance of winter temperature for dippers [Hegelbach, 2001]. Dippers started to breed around February and March, and earlier breeding was observed in mild winters; i.e., the date of first breeding was significantly related to water and air temperature in February. A comparison with earlier studies revealed that on average, the start of the breeding season in the 1990s was earlier than in previous decades. Hegelbach [2001] suggests that a faster development of invertebrate prey at warmer water temperatures links the breeding phenology of dippers with winter temperatures.

\section{BIOLOGICALLY MEDIATED RESPONSES}

\subsection{Water Chemistry}

The impact of the NAO on phytoplankton populations (see above) has indirect consequences for water chemistry. An increase in phytoplankton biomass, and probably also primary production, in response to mild winters is likely to result in changes in chemical variables such as $\mathrm{pH}$ and the concentrations of $\mathrm{O}_{2}$ and nutrients. In Plußsee [Güss et al., 2000] and in the Galten Basin of Lake Mälaren [Weyhenmeyer, in prep.], higher $\mathrm{O}_{2}$ concentrations as a consequence of increased $\mathrm{O}_{2}$ production, as well as higher $\mathrm{pH}$ and reduced concentrations of SRSi and ammonia resulting from an increased uptake of $\mathrm{CO}_{2}$ and nutrients, were observed to follow mild winters. In both lakes, some of these indirect phytoplankton-mediated effects of the NAO last until April and May [Güss et al., 2000; Weyhenmeyer, in prep.].

In addition, NAO-related changes in summer water chemistry can be traced back to changes in summer phytoplankton abundance. For example, increased epilimnetic $\mathrm{O}_{2}$ concentrations and increased $\mathrm{pH}$ correspond to decreased transparency (indicating a more intense phytoplankton bloom) in Plußsee in July and August [Güss et al., 2000]. In autumn, $\mathrm{O}_{2}$ concentrations are negatively related to the conditions in the previous winter, indicating an increase in the degradation of particulate organic matter originating from more intense phytoplankton blooms [Güss et al., 2000]. These results suggest that meteorological conditions in winter, and hence also the NAO, play a central role in explaining the chemistry of freshwater systems throughout the year.

\subsection{Food Web Interactions}

Populations interact with each other in food webs. The sensitivity and response of one particular population to increased water temperatures, for example, might therefore alter its interactions with competitors, mutualists, predators, prey, and pathogens. These possible indirect effects of cli- 
mate forcing related to the NAO might be especially important if critical species within a food web are affected. Small changes in a factor like water temperature could alter foodweb dynamics and generate system-wide ecological changes [Sanford, 1999; Scheffer et al., 2001b].

Clearly, Daphnia, which is both an important component of the diet of many fish species and an important consumer of phytoplankton and protozoa, is a critical species in lake food webs [Jürgens, 1994]. Grazing by Daphnia during its mass development in late spring/early summer suppresses phytoplankton populations, resulting in a so-called clearwater phase [Sommer et al., 1986]. In Lake Constance, higher spring water temperatures tend to result in higher Daphnia growth rates and biomass compared to years with lower water temperatures, resulting in turn in earlier occurrence of the clear-water phase [Straile, 2000]. Consequently, the timing of the clear-water phase in Lake Constance has been shown to be significantly related to the phase of the NAO, with a shared variance of $30 \%$ (Figure 4). Given the indirect nature of the relationship, which involves several intermediate steps (Figure 4) that are all significantly related to each other [Straile, 2000], this high percentage of shared variance is indeed remarkable.

In a subsequent study, Straile and Adrian [2000] showed that the observed patterns were not specific to Lake Constance, but could also be found in Müggelsee [but see Gerten and Adrian, 2000], a small polytrophic lake in Berlin that differs strongly from Lake Constance limnologically. Within both lakes, interannual variability in vernal warming and Daphnia population growth was found to be related to the interannual variability of the NAO. Furthermore, the timing of the clear-water phase in the two lakes was highly correlated $(\mathrm{r}=0.63, \mathrm{p}<0.05)$, indicating synchrony in the occurrence of successional events despite the great distance $(>700 \mathrm{~km})$ between the lakes [Straile and Adrian, 2000]. In addition, a link between the NAO (or winter temperatures) and the timing of the clear-water phase was also found in Plußsee, Germany [Müller-Navarra et al., 1997] and Lake Geneva, France/Switzerland [Anneville et al., 2002].

The spatial coherence in plankton succession across large regions due to the synchronizing impact of the NAO was

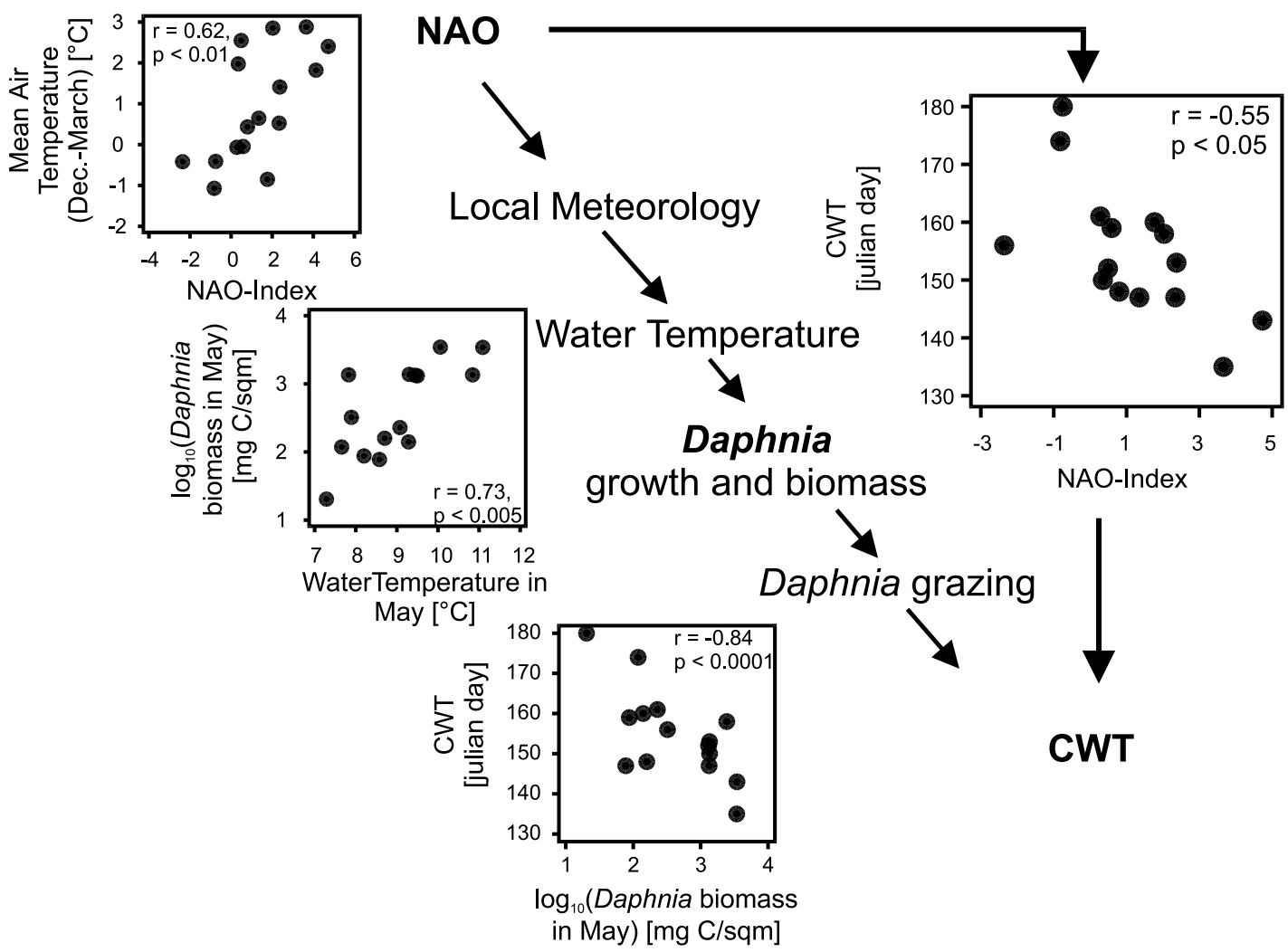

Figure 4. Diagram illustrating the propagation of the effects of the NAO on winter meteorological conditions through water temperature, Daphnia population growth and biomass on clear-water timing (CWT) in Lake Constance (modified from Straile [2000]). 
further investigated by Straile [2002]. He used the timing of the clear-water phase as a phenological marker and the link between it and the NAO as a proxy for the occurrence of the chain of effects depicted in Figure 4. He investigated the influence of the NAO on vernal warming and Daphnia population growth in 28 lakes across central Europe, encompassing an area of $>10^{5} \mathrm{~km}^{2}$ and an altitude range of almost $1000 \mathrm{~m}$. On average, the timing of the clear-water phase in these lakes was found to have advanced by 0.5 days per year (corresponding to approximately 2 weeks over the last three decades), and to have been strongly influenced by the NAO (Figure 5). The NAO has therefore been responsible for a synchronization of the plankton succession among central European lakes during the last few decades, giving rise to a large-scale coherence in successional patterns. Such coherence has hitherto only been found for abiotic variables in lake ecosystems [e.g., Magnuson et al., 1990; Kratz et al., 1998; Baines et al., 2000; Livingstone and Dokulil, 2001].

Further evidence for the large-scale coherence of successional events in central European lakes is given by the link between the phase of the NAO and the timing of the clearwater phase found by Scheffer et al. [2001a] in Dutch lakes. In contrast to the lakes chosen by Straile [2002], which show a distinct clear-water phase, the highly eutrophic Dutch lakes only rarely experience a clear-water phase. In those rare cases, early clear-water phases are associated with a positive phase of the NAO $\left(\mathrm{r}^{2}=0.21, \mathrm{p}<0.01\right)$. In addition, multiple logistic regression (the dependent variable is binary) shows that the probability of a clear-water phase in the Dutch lakes decreased with increasing average chlorophyll $a$ concentration ( $\mathrm{r}=-0.067, \mathrm{p}<0.001)$, but was

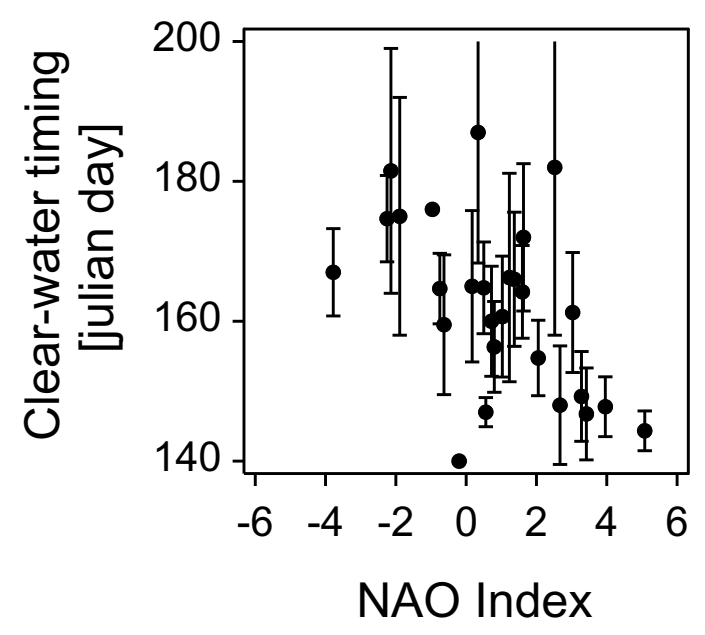

Figure 5. NAO impact on the timing of the clear-water phase in central European lakes. The average date of occurrence of the clear-water phase in a specific year is significantly related to the winter NAO index ( $<$ 0.05) (see Straile [2002] for details). positively related to the NAO index $(\mathrm{r}=0.335, \mathrm{p}<0.005)$. Scheffer et al. [2001a] show that the observed changes in the timing and occurrence of a clear-water phase can be reproduced remarkably well using a simple periodically forced algae-zooplankton model with temperature-dependent growth and mortality terms. Although some important mechanisms are not considered in this model (see below), it does show that even small temperature changes might crucially affect the dynamics of a lake system. In shallow lakes, a clear-water phase is not only a distinct phase of plankton succession but also represents an important window of opportunity for the growth and recolonization of submerged macrophytes. Hence it can also function as a possible switch between alternative stable states, from a system dominated by phytoplankton to one dominated by macrophytes [Scheffer et al., 1993]. This switch is regarded as a key process in the restoration of eutrophic lakes and has profound consequences for the entire food-web structure. Subtle changes in temperature associated with the NAO might therefore result in ecosystem regime shifts [Scheffer et al., 2001a].

However, high NAO index years might not always be associated with the suppression of algal growth and the establishment of a clear-water phase in summer, but rather with a Daphnia summer minimum and a consequent reduction in the grazing of algae. In Plußsee, summer phytoplankton blooms were found to be more intense after mild winters, and it was suggested that this could be due to a decrease in the abundance and grazing pressure of zooplankton in summer [Güss et al., 2000]. In the biomanipulated Bautzen Reservoir, high daphnid biomass during spring associated with a high NAO index (see above) was found to be the best single predictor for the occurrence of a Daphnia midsummer decline and low Daphnia abundance in summer [Benndorf et al., 2001]. The authors of this study even conclude that climate warming is a potential threat to successful biomanipulation. Low zooplankton abundance in summers following mild winters could in principle result from a beneficial effect of increased winter and early spring temperature on the recruitment (see above), growth and prey consumption of fish [Hill and Magnuson, 1990]. According to Benndorf et al. [2001], the match or mismatch sensu Cushing [1990] of Daphnia population development with peak predation of juvenile fishes is especially crucial for Daphnia population dynamics during summer [for examples on the importance of the match/mismatch mechanism in terrestrial ecosystems see Mysterud et al., this volume]. This again highlights the need for further studies on the impact of the NAO on freshwater fishes.

Why do mild winters increase the probability of a clearwater phase in Dutch lakes on the one hand, but result in 
lower Daphnia summer abundance in Bautzen Reservoir and more intense phytoplankton blooms in Plußsee on the other? A possible explanation might be related to differences in the mean depth of the lakes. All Dutch lakes are very shallow, and a clear-water phase can be stabilized by macrophytes providing a refuge for Daphnia and suppressing phytoplankton by allelochemicals [Scheffer et al., 1993; Benndorf et al., 2002]. In contrast, in Bautzen Reservoir and in Plußsee, the stabilization of a clear-water phase by macrophytes is not possible as the lakes are too deep to allow macrophyte growth over enough of the lake bottom. Consequently, the effect of climate variability on plankton dynamics might be different in shallow and deep lakes, partially because of the different opportunities they offer for macrophyte growth.

Clearly, the discussion of the indirect effects of the NAO must remain to some extent speculative. As they are "indirect", these effects are often difficult to detect and to understand. Nevertheless, an increasing body of evidence suggests that indirect, food-web mediated effects of the NAO (and indeed of winter warming in general) are very important. These effects can propagate far into the following growing season, possibly resulting in ecosystem-wide regime shifts [Scheffer et al., 2001a].

\section{SUMMARY AND CONCLUSIONS}

Research on the influence of the NAO on freshwater ecosystems is still in its early stages. However, the tremendous impact of the NAO on the physics, chemistry and biology of many Northern Hemisphere lakes is already apparent. Of course, much of the variability in any one freshwater ecosystem is not related to the NAO. However, the impact of the NAO is strong enough to result in a striking coherence in many of the physical and biological characteristics of freshwater ecosystems over a very large area. Large-scale coherent responses to the NAO have been observed, for instance, in the case of ice phenology [Livingstone, 2000], spring surface temperatures [Livingstone and Dokulil, 2001] and the successional dynamics of lake plankton [Straile, 2002; Weyhenmeyer et al., 2002]. This high degree of coherence, which is observed even among lakes which differ strongly limnologically - for example with respect to trophic status - gives aquatic ecologists a tool which they can use to disentangle the effects of climatic changes on lakes from the effects of direct human impact (e.g. eutrophication).

To a large extent, the strong, coherent impact of the NAO on European lakes is a result of the time of year during which the NAO most strongly affects the European climate; viz. winter and early spring. This time of year, dur- ing which both spring turnover and the onset of stratification occur, is critical for lakes. Because of this, the NAO can have a major impact on the distribution and seasonal development of temperature and nutrients, and is able to influence both the time of onset and the rate of plankton succession.

Although the signature of the winter NAO is detectable in regional air temperatures in central Europe only up until March, it can persist in lake surface water temperatures until May [Livingstone and Dokulil, 2001]. Because deep-water temperatures are generally determined by the temperature attained during partial or total homothermy in early spring and change comparatively little after the onset of stratification [Livingstone, 1993], the signature of the winter NAO present in the lake temperature in spring can persist much longer in the hypolimnion than in the epilimnion [Figure 2; Straile and Adrian, 2000; Gerten and Adrian, 2001]. This has implications for respiration rates in the hypolimnion, and hence for the rate of oxygen depletion there [Livingstone, 1997a].

Food-web interactions result in a prolongation of the effects of the NAO on lake biology. The impact of the NAO is detectable, for instance, in the timing of the clear-water phase in early summer [Straile and Adrian, 2000; Straile, 2002]. Likewise, evidence suggests that the NAO affects phytoplankton populations and lake chemistry in summer and autumn, although the mechanisms linking winter meteorology to lake chemistry and biology in summer are complex and not yet clear [Güss et al., 2000; Weyhenmeyer, in prep.]. Finally, in shallow lakes the switch from domination by phytoplankton to domination by macrophytes in summer may be influenced by the climatic conditions prevailing in winter and early spring, and hence also by the NAO [Scheffer et al., 2001a].

The impact of the NAO on a freshwater ecosystem depends critically on its size and geographical location. As the NAO affects air temperature and precipitation differently in different regions [Hurrell, 1995], the response of lakes and rivers will obviously also be different. For instance, increased precipitation in northern and western Europe in high NAO index years results in increased river discharge in these regions [e.g., Kiely, 1999; Hänninen et al., 2000], while decreased precipitation in high NAO index years lowers river discharge in southern Europe and the Middle East [Cullen and deMenocal, 2000; Lloret et al., 2001]. However, even within one particular climatic region, different lake responses might occur at different altitudes or latitudes. The impact of the NAO on the leaching of nutrients from soil and subsequent March nutrient concentrations in lakes differs between lakes in Sweden and the UK because of differences in average winter severity, which affects 
whether the soil is frozen or not, although air temperatures in both Sweden and the UK are positively correlated with the winter NAO index. The response of lake surface water temperature to the NAO depends on the altitude of the lake, because high-altitude lakes tend to be ice-covered longer, protecting the lake from the impact of the winter NAO [Livingstone and Dokulil, 2001]. Lake temperatures in highaltitude or high-latitude lakes that thaw in early summer instead of spring are unlikely to show a strong NAO signal, because the climatic influence of the NAO at this time of year is comparatively weak. However, the NAO will affect the timing of ice-out of such lakes [Livingstone, 2000].

In addition to altitude and latitude, lake size and depth also matter. Small lakes with low water turnover times are more susceptible to fluctuations in inflow associated with the NAO than are large lakes. In contrast, only deep lakes are sensitive to NAO-related effects on spring turnover, as shallow lakes mix completely after every winter regardless of the state of the NAO. The depth of a lake further determines the response of its hypolimnetic water temperatures to the NAO and the persistence of the NAO signal produced. As the response of lacustrine plant and animal populations to the NAO is mediated by lake physics and chemistry, the population responses are likely to differ among freshwater systems depending on altitude, latitude, size and depth.

Recent internationally-based analyses of the impact of the NAO on freshwater ecosystems across large areas of the Northern Hemisphere are providing an improved understanding of the large-scale mechanisms responsible for spatially coherent interannual fluctuations in physical, chemical and biological lake variables. As the current tendency for the NAO to remain in its positive phase may be stabilized by increased concentrations of greenhouse gases [Paeth et al., 1999; see also Gillett et al., this volume], the current series of unusually warm winters in Europe may be set to continue. A better understanding of the large-scale role played by the NAO in determining the functioning of freshwater ecosystems is urgently needed to predict the consequences of such a development.

Acknowledgements. We thank John J. Magnuson and two anonymous referees for comments and suggestions. Funding was provided by the European Union (Contract No. ENV4-CT970453) and the Swiss Federal Office of Education and Science (BBW; Contract No. 97.0344) within the framework of the European Union Environment and Climate project REFLECT ("Response of European Freshwater Lakes to Environmental and Climatic Change").

\section{REFERENCES}

Adrian, R., Calanoid-cyclopoid interactions: evidence from an 11-year field study in a eutrophic lake, Freshw. Biol., 38, 315-325, 1997.
Adrian, R., N. Walz, T. Hintze, S. Hoeg, and R Rusche, Effects of ice duration on the plankton succession during spring in a shallow polymictic lake, Freshw. Biol., 41, 621-623, 1999.

Anderson, W. L., D. M. Robertson, and J. J. Magnuson, Evidence of recent warming and El-Niño-related variations in ice breakup of Wisconsin lakes, Limnol. Oceanogr., 41, 815-821, 1996.

Anneville, O., S. Soussi, F. Ibañez, V. Ginot, J.-C. Druart, and N. Angeli, Temporal mapping of phytoplankton assemblages in Lake Geneva: annual and interannual changes in their patterns of succession, Limnol. Oceanogr., 47, 1355-1366, 2002.

Arai, T., Climatic and geomorphological influences on lake temperature, Verh. Internat. Verein. Limnol., 21, 130-134, 1981.

Baines, S. B., K. E. Webster, T. K. Kratz, S. R. Carpenter, and J. J. Magnuson, Synchronous behavior of temperature, calcium, and chlorophyll in lakes of northern Wisconsin, Ecology, 81, 815$825,2000$.

Benndorf, J., W. Böing, J. Koop, and I. Neubauer, Top-down control of phytoplankton: the role of time-scale, lake depth and trophic state, Freshw. Biol., in press, 2002.

Benndorf, J., J. Kranich, T. Mehner, and A. Wagner, Temperature impact on the midsummer decline of Daphnia galeata: an analysis of long-term data from the biomanipulated Bautzen Reservoir (Germany), Freshw. Biol., 46, 199-211, 2001.

Bradley, D. C., and S. J. Ormerod, Community persistence among stream invertebrates tracks the North Atlantic Oscillation, J. Anim. Ecol., 70, 987-996, 2001.

Cullen, H. M., and P. B. deMenocal, North Atlantic Influence on Tigris-Euphrates streamflow, Int. J. Climatol., 20, 853-863, 2000.

Cushing, D. H., Plankton production and year-class strength in fish populations: an update of the match/mismatch hypotheses, $A d v$. Mar. Biol., 26, 249-293, 1990.

Dingman, S. L., Equilibrium temperatures of water surfaces as related to air temperature and solar radiation, Water Resour. Res., 8, 42-49, 1972.

Drinkwater, K. F., A. Belgrano, A. Borja, A. Conversi, M. Edwards, C. H. Greene, G. Ottersen, A. J. Pershing, and H. Walker, The response of marine ecosystems to climate variability associated with the North Atlantic Oscillation, this volume.

Eckmann, R., U. Gaedke, and H. J. Wetzlar, Effects of climatic and density-dependent factors on year-class strength of Coregonus lavaretus in Lake Constance, Can. J. Fish. Aquat. Sci., 45, 10881093, 1988.

Edinger, J. E., D. W. Duttweiler, and J. C. Geyer, The response of water temperatures to meteorological conditions, Water Resour. Res., 4, 1137-1143, 1968.

Elliott, J. M., Temperature-related fluctuations in the timing of emergence and pupation of Windermere alder-flies over 30 years, Ecol. Entomol., 21, 241-247, 1996.

Elliott, J. M., and M. A. Hurley, An individual-based model for predicting the emergence period of sea trout fry in a Lake District stream, J. Fish. Biol., 53, 414-433, 1998.

Elliott, J. M., M. A. Hurley, and S. C. Maberly, The emergence period of sea trout fry in a Lake District stream correlates with the North Atlantic Oscillation, J. Fish. Biol., 56, 208-210, 2000.

Evans, C. D., D. T. Monteith, and R. Harriman, Long-term variability in the deposition of marine ions at west coast sites in the 
UK acid waters monitoring network: impacts on surface water chemistry and significance for trend determination. The Science of the total Environment, 265, 115-129, 2001.

Firth, P., and S. G. Fisher (eds.), Global climate change and freshwater ecosystems, 321 pp., Springer, Berlin, 1992.

Fromentin, J. M., N. C. Stenseth, J. Gjosaeter, T. Johannessen, and B. Planque, Long-term fluctuations in cod and pollack along the Norwegian Skagerrak coast, Mar. Ecol. Prog. Ser., 162, 265278, 1998.

Gaedke, U., D. Ollinger, E. Bäuerle, and D. Straile, The impact of the interannual variability in hydrodynamic conditions on the plankton development in Lake Constance in spring and summer, Arch. Hydrobiol. Spec. Issues Advanc. Limnol., 53, 565-585, 1998.

George, D. G., Using 'climate indicators' to monitor patterns of change in freshwater lakes and reservoirs, in Water in the Celtic world: managing resources for the 21st century, edited by J. A. A. Jones, K. Gilman, A Jigorel, and J. Griffin, pp. 93-102, British Hydrological Society, Occasional Papers 11, 2000a.

George, D. G., The impact of regional-scale changes in the weather on the long-term dynamics of Eudiaptomus and Daphnia in Esthwaite Water, Cumbria, Freshw. Biol., 45, 111-121, $2000 \mathrm{~b}$.

George, D. G., Regional-scale influences on the long-term dynamics of lake plankton, in Phytoplankton Productivity: Carbon Assimilation in Marine and Freshwater Ecosystems, edited by P. J. le B Williams, D. N. Thomas, and C. S. Reynolds, Blackwell Science, 265-290, 2002.

George, D. G., and D. P. Hewitt, The influence of year-to-year variations in winter weather on the dynamics of Daphnia and Eudiaptomus, in Estwaite Water, Cumbria, Funct. Ecol., 13(Suppl.1), 45-54, 1999.

George, D. G., J. F. Talling, and E. Rigg, Factors influencing the temporal coherence of five lakes in the English Lake Distict, Freshw. Biol., 43, 449-461, 2000.

George, D. G., and A. H. Taylor, UK lake plankton and the Gulf stream, Nature, 378, 139-1995.

Gerten, D., and R. Adrian, Climate-driven changes in spring plankton dynamics and the sensitivity of shallow polymictic lakes to the North Atlantic Oscillation, Limnol. Oceanogr., 45, 1058-1066, 2000.

Gerten, D., and R. Adrian, Differences in the persistency of the North Atlantic Oscillation signal among lakes, Limnol. Oceanogr., 46, 448-455, 2001.

Gillett, N. P., H. F. Graf, and T. J. Osborn, Climate change and the North Atlantic Oscillation, this volume.

Güss, S., D. Albrecht, H.-J. Krambeck, D. C. Müller-Navarra, and H. Mumm, Impact of weather on a lake ecosystem, assessed by cyclo-stationary MCCA of long-term observations, Ecology, 81, 1720-1735, 2000.

Hänninen, J., I Vuorinen, and P. Hjelt, Climatic factors in the Atlantic control the oceanographic and ecological changes in the Baltic Sea, Limnol. Oceanogr., 45, 703-710, 2000.

Hegelbach, J., Wassertemperatur und Blütenphänologie als Anzeiger des früheren Brutbeginns der Wasseramsel (Cinclus cinclus) im schweizerischen Mittelland, J. Ornithol., 142, 284294, 2001.

Henderson-Sellers, B., Sensitivity of thermal stratification models to changing boundary conditions, Appl. Math. Mod., 12, 31-43, 1988.
Hill, D. K., and J. J. Magnuson, Potential effects of global climate warming on the growth and prey consumption of Great Lakes fishes, Trans. Am. Fish. Soc., 119, 265-275, 1990.

Hondzo, M., and H. G. Stefan, Propagation of uncertainty due to variable meteorological forcing in lake temperature models, Water Resour. Res., 28, 2629-2638, 1992.

Hondzo, M., and H. G. Stefan, Regional water temperature characteristics of lakes subjected to climate change, Clim. Change, 24, 187-211, 1993.

Huisman, J., R. R. Jonker, C. Zonneveld, and F. J. Weissing, Competition for light between phytoplankton species: experimental tests of mechanistic theory, Ecology, 80, 211-222, 1999.

Hurrell, J. W., Decadal trends in the North Atlantic Oscillation: regional temperatures and precipitation, Science, 269, 676-679, 1995.

Hurrell, J. W., Influence of variations in extratropical wintertime teleconnections on Northern Hemisphere temperatures, Geophys. Res. Lett., 23, 665-668, 1996.

Hurrell, J. W., and H. van Loon, Decadal variations in climate associated with the North Atlantic Oscillation, Clim. Change, 36, 301-326, 1997.

Hurrell, J. W., Y. Kushnir, G. Ottersen, and M. Visbeck, An Overview of the North Atlantic Oscillation, this volume.

Jones, P. D., T. J. Osborn, and K. R. Briffa, Pressure-based measures of the North Atlantic Oscillation (NAO): A comparison and an assessment of changes in the strength of the NAO and in its influence on surface climate parameters, this volume.

Jürgens, K., Impact of Daphnia on planktonic microbial food webs - A review, Mar. Microb. Food Webs, 8, 295-324, 1994.

Kiely, G., Climate change in Ireland from precipitation and streamflow observations, Adv. Water Res., 23, 141-151, 1999.

Kratz, T. K., P. A. Soranno, S. B. Baines, B. J. Benson, J. J. Magnuson, T. M. Frost, and R. C. Lathrop, Interannual synchronous dynamics in north temperatue lakes in Wisconsin, USA, in Management of Lake and Reservoirs during Global Climate Change, edited by D. G. George, J. G. Jones, P. Puncochar, C. S. Reynolds, and D. W. Sutcliffe, pp. 273-287, Kluwer Academic Publishers, 1998.

Livingstone, D. M., Temporal structure in the deep-water temperature of four Swiss lakes: a short-term climatic change indicator? Verh. Internat. Verein. Limnol., 25, 75-81, 1993.

Livingstone, D. M., An example of the simultaneous occurrence of climate-driven "sawtooth" deep-water warming/cooling episodes in several Swiss lakes, Verh. Internat. Verein. Limnol., 26, 822-826, 1997a.

Livingstone, D. M., Break-up dates of Alpine lakes as proxy data for local and regional mean surface air temperatures, Clim. Change, 37, 407-439, 1997b.

Livingstone, D. M., Ice break-up on southern Lake Baikal and its relationship to local and regional air temperatures in Siberia and to the North Atlantic Oscillation, Limnol. Oceanogr., 44, 14861497, 1999.

Livingstone, D. M., Large-scale climatic forcing detected in historical observations of lake ice break-up, Verh. Internat. Verein. Limnol., 27, 2775-2783, 2000.

Livingstone, D. M., and M. T. Dokulil, Eighty years of spatially coherent Austrian lake surface temperatures and their relation- 
ship to regional air temperature and the North Atlantic Oscillation, Limnol. Oceanogr., 46, 1220-1227, 2001.

Livingstone, D. M., and D. M. Imboden, The prediction of hypolimnetic oxygen profiles: a plea for a deductive approach, Can. J. Fish. Aquat. Sci., 53, 924-932, 1996.

Livingstone, D. M., and A. F. Lotter, The relationship between air and water temperatures in lakes of the the Swiss plateau: a case study with paleolimnological implications, J. Paleolimnol., 19, 181-198, 1998.

Livingstone, D. M., A. F. Lotter, and I. R. Walker, The decrease in summer surface water temperature with altitude in Swiss alpine lakes: a comparison with air temperature lapse rates, Arct. Antarct. Alpine Res., 31, 341-352, 1999.

Lloret, J., J. Lleonart, I Solé, and J. M. Fromentin, Fluctuations of landings and environmental conditions in the north-western Mediterranean Sea, Fish. Oceanogr., 10, 33-50, 2001.

Magnuson, J. J., B. J. Benson, and T. K. Kratz, Temporal coherence in the limnology of a suite of lakes in Wisconsin, U.S.A., Freshw. Biol., 23, 145-159, 1990.

Magnuson, J. J., et al., Historical trends in lake and river ice cover in the Northern Hemisphere, Science, 289, 1743-1746, 2000.

McCombie, A. M., Some relations between air temperature and the surface water temperatures of lakes. Limnol. Oceanogr., 4, 252258, 1959.

Mehner, T., H. Dörner, and H. Schultz, Factors determining the year-class strength of age-0 Eurasian perch (Perca fluviatilis L.) in a long-term biomanipulated reservoir. Archive of Fishery and Marine Research, 46, 241-251, 1998.

Monteith, D. T., C. D. Evans, and B. Reynolds, Are temporal variations in the nitrate content of UK upland freshwaters linked to the North Atlantic Oscillation? Hydrological Processes, 14, 1745-1749, 2000.

Müller-Navarra, D. C., S. Güss, and H. von Storch, Interannual variability of seasonal succession events in a temperate lake and its relation to temperature variability, Global Change Biology, 3, 429-438, 1997.

Mysterud, A., N. C. Stenseth, N. G. Yoccoz, G. Ottersen, and R. Langvatn, The response of terrestrial ecosystems to climate variability associated with the North Atlantic oscillation, this volume.

Oschlies, A., NAO-induced long-term changes in nutrient supply to the surface waters of the North Atlantic, Geophys. Res. Lett., 28, 1751-1754, 2001.

Ottersen, G., and H. Loeng, Covariability in early growth and yearclass strength of Barents Sea cod, haddock and herring: the environmental link, ICES Journal of Marine Science, 57, 339-348, 2000.

Ottersen, G., B. Planque, A. Belgrano, E. Post, and N. C. Stenseth, Ecological effects of the North Atlantic Oscillation, Oecologia, 128, 1-18, 2001.

Paeth, H., A. Hense, R. Glowienka-Hense, R. Voss, and U Cubasch, The North Atlantic Oscillation as an indicator for greenhouse-gas induced regional climate change, Clim. Dynamics, 15, 953-960, 1999.

Palecki, M. A., and R. G. Barry, Freeze-up and break-up of lakes as an index of temperature changes during the transition seasons: a case study for Finland, J. Clim. Appl. Meteor., 25, 893-902, 1986.

Raven, J. A., and R. J. Geider, Temperature and algal growth. New Phytol., 110, 1988.

Reynolds, C. S., Physical determinants of phytoplankton succession, in Plankton ecology: succession in plankton communities, edited by U. Sommer, pp. 9-56, Springer, Berlin, 1989.

Robertson, D. M., The use of lake water temperature and ice cover as climatic indicators, $\mathrm{PhD}$ diss., University of Wisconsin, Madison, Wisconsin. 265 pp. 1989.

Robertson, D. M., and R. A. Ragotzkie, Changes in the thermal structure of moderate to large sized lakes in response to changes in air temperature, Aquat. Sci., 52, 360-380, 1990.

Robertson, D. M., R. A. Ragotzkie, and J. J. Magnuson, Lake ice records used to detect historical and future climatic changes. Clim. Change, 21, 407-427, 1992.

Rodionov, S. N., Global and regional climate interaction: the Caspian Sea experience, Kluwer, Dordrecht, 1994.

Ruosteenoja, K., The date of break-up of lake ice as a climatic index, Geophysica, 22, 89-99, 1986.

Sanford, E., Regulation of keystone predation by small changes in ocean temperature, Science, 283, 2095-2097, 1999.

Sæther, B.-E., J. Tufto, S. Engen, K. Jerstad, O. W. Røstad, and J. E Skåtan, Population dynamical consequences of climate change for a small temperate songbird, Science, 287, 854-856, 2000.

Scheffer, M., S. Carpenter, C. Foley, and B. Walker, Catastrophic shifts in ecosystems, Nature, 413, 591-596, 2001b.

Scheffer, M., S. H. Hosper, M. L. Meijer, B. Moss, and E. Jeppesen, Alternative equilibria in shallow lakes, Trends Ecol. Evol., 8, 275-279, 1993.

Scheffer, M., D. Straile, E. H. van Nes, and H. Hosper, Climatic warming causes regime shifts in lake food webs, Limnol. Oceanogr., 46, 1780-1783, 2001a.

Schindler, D. W., Widespread effects of climatic warming on freshwater ecosystems in North America, Hydrol. Process., 11, 10431067, 1997.

Shuter, B. J., D. A. Schlesinger, and A. P. Zimmerman, Empirical predictors of annual surface water temperature cycles in North American Lakes, Can. J. Fish. Aquat. Sci., 40, 1838-1845, 1983.

Sommer, U., The role of competition for resources in phytoplankton succession, in Plankton ecology: succession in plankton communities, edited by U. Sommer, pp. 57-106, Springer, Berlin, 1989.

Sommer, U., Z. M. Gliwicz, W. Lampert, and A. Duncan, The PEG-model of seasonal succession of planktonic events in fresh waters, Arch. Hydrobiol., 106, 433-471, 1986.

Stenseth, N. C., O. N. Bjørnstad, W. Falck, J. M. Fromentin, J. Gjosaeter, and J. S. Gray, Dynamics of coastal cod populations: intra- and intercohort density dependence and stochastic processes, Proc. R. Soc. Lond. B, 266, 1645-1654, 1999.

Straile, D., Meteorological forcing of plankton dynamics in a large and deep continental European lake, Oecologia, 122, 44-50, 2000.

Straile, D., North Atlantic Oscillation synchronizes food-web interactions in central European lakes, Proc. R. Soc. Lond. B, 269, 391-395, 2002. 
Straile, D., and R. Adrian, The North Atlantic Oscillation and plankton dynamics in two European lakes - two variations on a general theme, Global Change Biology, 6, 663-670, 2000.

Strub, P. T., T. Powell, and C. R. Goldman, Climatic forcing: effects of El Niño on a small, temperate lake, Science, 227, 5557, 1985.

van Loon, H., and R. A. Madden, Interannual variations of mean monthly sea-level pressure in January, J. Clim. Appl. Meteor, 22, 687-692, 1983.

Vavrus, S. J., R. H. Wynne, and J. A. Foley, Measuring the sensitivity of southern Wisconsin lake ice to climate variations and lake depth using a numerical model, Limnol. Oceanogr., 41, 822-831, 1996.

Weyhenmeyer, G. A., Warmer winters-are planktonic algal populations in Swedens largest lakes affected? Ambio, 30, 565-571, 2001.

Weyhenmeyer, G. A., R. Adrian, U. Gaedke, D. M. Livingstone, and S. C. Maberly, Response of phytoplankton in European lakes to a change in the North Atlantic Oscillation, Verh. Internat. Verein. Limnol., in press, 2002.

Weyhenmeyer, G. A., T. Blenckner, and K. Pettersson, Changes of the plankton spring outburst related to the North Atlantic Oscillation, Limnol. Oceanogr., 44, 1788-1792, 1999.
Williams, R. G., and A. J. McLaren, Estimating the convective supply of nitrate and implied variability in export production over the North Atlantic, Global Biogeochem. Cycles, 14, 1299-1313, 2000 .

Dietmar Straile, Limnological Institute, University of Konstanz, 78457 Konstanz, Germany.

Dietmar.Straile@uni-konstanz.de

David M. Livingstone, Water Resources Department, Swiss Federal Institute of Environmental Science and Technology (EAWAG), Überlandstrasse 133, CH-8600 Dübendorf, Switzerland.

living@eawag.ch

Gesa A. Weyhenmeyer, Department of Environmental Assessment, Swedish University of Agricultural Sciences, P.O. Box 7050, 75007 Uppsala, Sweden.

Gesa.Weyhenmeyer@ma.slu.se

D. Glen George, Centre for Ecology and Hydrology, The Ferry House, Far Sawrey, Ambleside, Cumbria LA22 OLP, U.K.

DGG@ceh.ac.uk 